DOI: $10.25140 / 2411-5215-2020-1(21)-309-320$

Kateryna Hnedina, Artem Vertiiko

\title{
FORMATION OF STRATEGIC MANAGEMENT ACCOUNTING SYSTEM FOR A STARTUP ENTERPRISE
}

\section{Катерина Гнедіна, Артем Вертійко \\ ФОРМУВАННЯ СИСТЕМИ СТРАТЕГІЧНОГО УПРАВЛІНСЬКОГО ОБЛІКУ ДЛЯ СТАРТАП-ПІДПРИЕМСТВА}

\section{Екатерина Гнедина, Артём Вертейко \\ ФОРМИРОВАНИЕ СИСТЕМЫ СТРАТЕГИЧЕСКОГО УПРАВЛЕНЧЕСКОГО УЧЁТА ДЛЯ СТАРТАП-ПРЕДПРИЯТИЯ}

The article is devoted to the research of theoretical and methodical foundations of the functioning of the strategic management accounting system and the elaboration of practical recommendations for its formation at a startup enterprise in terms of digitization. The essence of the category "strategic management accounting system" and its main characteristics are defined. Core directions of the formation of a strategic management accounting system depending on the stages of life cycle of a startup are described. Forms of reports are developed, which are recommended to be implemented at a startup enterprise in order to monitor the directions of funds' consumption and to control the costs for innovative activity.

Keywords: management accounting; strategic management accounting; budgeting; management accounting automation; startup; strategy; internal reporting; digitalization.

Fig.: 3. Table: 5. References: 12.

Стаття присвячена дослідженню теоретико-методичних основ функиіонування системи стратегічного управлінського обліку та розробці практичних рекомендачій щодо ї̈ формування на стартап-підприємстві в умовах діджиталізації. Визначено сутність категорії «система стратегічного управлінського обліку» та наведено їі основні характеристики. Виокремлено ключові напрями формування системи стратегічного управлінського обліку залежно від стадій життєвого ииклу стартапу. Розроблено форми звітів, які рекомендовані до впровадження на стартап-підприсмстві з метою моніторингу напрямів споживання коштів та забезпечення контролю витрат інновачійної діяльності.

Ключові слова: управлінський облік; стратегічний управлінський облік; бюджетування; автоматизачія управлінського обліку; стартап; стратегія; внутрішня звітність; діджиталізація.

Рис .: 3. Табл.: 5. Бібл.: 12.

Статья посвящена исследованию теоретико-методических основ функиионирования системы стратегического управленческого учёта и разработке практических рекомендаций по её формированию на стартап-предприятии в условиях диджитализации. Определена сущность категории «система стратегического управленческого учёта» и приведены её основные характеристики. Выделены ключевые направления формирования системы стратегического управленческого учёта в зависимости от стадий жизненного иикла стартапа. Разработаны формы отчётов, которые рекомендованы к внедрению на стартап-предприятии с иелью мониторинга направлений потребления средств и обеспечения контроля расходов инновачионной деятельности.

Ключевые слова: управленческий учёт; стратегический управленческий учёт; бюджетирование; автоматизация управленческого учёта; стартап; стратегия; внутренняя отчётность; диджитализация.

Рис.: 3. Табл.: 5. Библ.: 12.

JEL Classification: M41

Target setting. In the conditions of dynamic external changes and consumer's needs transformations, a significant number of startups are forming. They start with an innovative idea and turn into a revenue-generating business. Startups are developing at a rapid pace in the world, and an increasing number of startups in different fields are emerging in Ukraine. They play a significant role in the innovative development of the country's economy, so it is very important to ensure their successful functioning and development from small businesses to large ones. One of the factors for a successful startup is the effective resources management, in particular - management of financial resources, which can be both own and involved. Because startups typically attract resources for their development from outside sources (grants, business angels, venture funds, etc.), it is very important to ensure that these resources are accurately and fully accounted for and that a transparent system of cost reporting is established. In addition, it is necessary to form a strategic plan to overcome the threats of development and further scale up the business. The complex of these tasks can be solved 
ФІНАНСОВІ РЕСУРСИ: ПРОБЛЕМИ ФОРМУВАННЯ ТА ВИКОРИСТАННЯ

within the system of strategic management accounting, the formation of which should be in managers' focus at a startup enterprise. That is why it is relevant to determine the directions of development of strategic management accounting system for startups. For today startups operate in the context of global digitization, that leads to the automation of accounting and management processes, which should be taken into account during formation of strategic management accounting system.

Actual scientific researches and issues analysis. The essence of strategic management accounting and its role in entity's activity was investigated by such foreign scientist, as Ward K., Bromwich M., Cooper R., Kaplan R., Innes J., Lord B., Simmonds K. and many others. The issue of strategic management accounting was reviewed in the scientific works of national economists, among them: Y. Kuzminskyi, M. Voronova, Z. Hutsailiuk, A. Shaikan, P. Atamas. Problems of organization and development of innovative enterprises and startups were investigated by such scientists as: A. Kovaleva, N. Ivashova, O. Pomorova, V. Pikul, D. Zbanatsky, O. Matsevich, M. Barabash, O. Marchenko, J. Govorukha, L. Smolyar, L. Gladka, E. Kolesnik and many others. The problem of accounting for startups at different stages of their implementation was described in the article of such scientists, as S. Bezruchuk and O. Ostapchuk.

Uninvestigated parts of general matters defining. Despite the numerous research papers concerning strategic management and startups development, the problem of formation the strategic management accounting system for a startup enterprise is uninvestigated. It determines the relevance and timeliness of this investigation.

The purpose of the article is to define the essence of the strategic management accounting system and to give practical recommendations on its formation at a startup enterprise.

In order to achieve the purpose, the following tasks were set and solved during the investigation:

- to investigate approaches to the interpretation of strategic management accounting system, to determine its essence and main characteristics;

- to identify the peculiarities of forming a strategic accounting system for a startup company depending on the stage of the startup life cycle and the tools, that should be applied at each stage of development;

- to define the benefits of strategic management accounting`s automation and to propose approaches to automating strategic management accounting at a startup enterprise;

- to elaborate forms of reporting in order to control the costs of innovation activity of a startup;

- to develop a questionnaire to monitor the strategic management accounting system for a startup enterprise.

Research methods. The following research methods were used during investigation: monograph method - to study the scientific works devoted to the organization of strategic management accounting at the enterprise; methods of generalization and classification - to review the approaches of national and foreign scientists to the interpretation of the concept of "strategic management accounting"; methods of induction and deduction, analysis and synthesis - to investigate the peculiarities of strategic management accounting at a startup enterprise; systematic methods and analytical method - to give recommendations for improving the strategic management accounting system for startups; tabular method - to present the results of the research.

The statement of basic materials. To study the peculiarities of forming a strategic management accounting system for startups, it is necessary to determine the essence of the concept of "strategic management accounting" and to define its specific features and advantages. The review of the approaches to defining the category "strategic management accounting" by foreign and national scientists is presented in Table 1. 
Definition of the category "strategic management accounting" by foreign and national scientists

\begin{tabular}{|l|l|}
\multicolumn{1}{|c|}{ Definition/Source } & \multicolumn{1}{|c|}{$\begin{array}{c}\text { Author(s)/ } \\
\text { Year of publication }\end{array}$} \\
\hline $\begin{array}{l}\text { "The provision and analysis of information about a business and its competitors for use } \\
\text { in developing and monitoring the business strategy" [1] }\end{array}$ & K. Simmonds, 1981 \\
\hline $\begin{array}{l}\text { "Provision and analysis of financial information on the firm's product markets and com- } \\
\text { petitors' costs and cost structures and the monitoring of the enterprise's strategies and } \\
\text { those of its competitors in these markets over a number of periods" [2] }\end{array}$ & M. Bromwich, 1990 \\
\hline "The provision of information to support the strategic decisions in the organisations" [3] & J. Innes, 1998 \\
\hline $\begin{array}{l}\text { "The body of management accounting concerned with strategically orientated infor- } \\
\text { mation for decision making and control" [4] }\end{array}$ & $\begin{array}{l}\text { Ma Y. and Tayles } \\
\text { M., 2009 }\end{array}$ \\
\hline $\begin{array}{l}\text { Strategic management accounting is a system that provides information about the exter- } \\
\text { nal environment for strategic management and is formed in the controlling system** [5] }\end{array}$ & Mushkar, 1999 \\
\hline $\begin{array}{l}\text { Strategic management accounting should focus on external factors (such as profitability } \\
\text { of competitors, market share, etc.), while traditional accounting is characterized by a } \\
\text { focus on internal processes and phenomena ** [6] }\end{array}$ & Ptamas, 2006 \\
\hline $\begin{array}{l}\text { Strategic management accounting provides information support for managerial decision } \\
\text { making in all five interconnected strategic management processes. It not only selects } \\
\text { and implements the strategy, but also comprehensively monitors performance indicators } \\
\text { to track changes in external and internal environments that may need to be corrected by } \\
\text { an existing strategic enterprise development plan ** [7] }\end{array}$ & \\
\hline $\begin{array}{l}\text { ** it is translated by the authors. } \\
\text { Source: [1-7]. }\end{array}$
\end{tabular}

There is a common point of view among the authors, that strategic management accounting provides management personnel with information to make strategic management decisions and to form a business strategy. This information relates to the external environment: the market, competitors, strategies of other companies.

The characteristic feature of strategic management accounting is that it takes into account not only the internal factors of the microenvironment, but also the external factors of the macroenvironment, that affect the enterprise and provides management personnel with the information necessary to plan the future strategy of functioning of the enterprise in general and of certain responsibility centers [8].

In our opinion, strategic management accounting performs not only the function of providing the information to management personnel for strategy formation. Within the system of strategic management accounting the activity of the enterprise and its departments is planning, the key factors of success are determining, the results are evaluating according to the certain system of criteria. Strategic management accounting forms a unified information system for strategic analysis and strategic management of the enterprise.

The main task of strategic management accounting is to orient the enterprise management system to the achievement of strategic goals, taking into account the impact of changes in the environment. Strategic management decisions are aimed at increasing the economic potential of the enterprise and its competitiveness, ensuring the sustainable development of the business entity [8].

The organization of strategic management accounting at a startup enterprise has a range of peculiarities. Management objects at a startup enterprise are: resources (fixed assets, intangible assets, materials, financial resources, personnel, etc.); processes implemented by a startup enterprise: organization of activities, supply of resources, creation of an innovative products, sales of products and/or provision of services, marketing; results of activity. The strategic management accounting system should provide complete, accurate, relevant, timely information about these objects to users for decision-making. Therefore, the formation of strategic management accounting system should be approached comprehensively. 
ФІНАНСОВІ РЕСУРСИ: ПРОБЛЕМИ ФОРМУВАННЯ ТА ВИКОРИСТАННЯ

The strategic management accounting system at a startup enterprise should be an integrated startup management system, that includes an accounting subsystem, information support, analysis, planning, monitoring, control in order to achieve the strategic goals of the business project (Figure 1).

Strategic management accounting system for a startup enterprise is an integrated management system, which includes the subsystem of accounting, information support, analysis, planning, monitoring, control in order to achieve the strategic goals of the business project.

Formation of strategic management accounting system at a startup enterprise provides:

- Defining the mission and goals of the startup enterprise;

- Formation of the strategic plans;

- Accounting and analytical support for strategic management decisions;

- Generalization and systematization of information necessary for management decisions;

- Creating the information system, managing information flows at the enterprise;

- Definition of methods and tools of analysis, planning, control;

- Encouragement of achievement of strategic goals;

- Performance monitoring, variance analysis, adjustment of enterprise management.

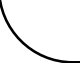

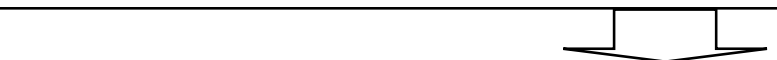

\section{Startup enterprise management objects:}

1) Resources (fixed assets, intangible assets, materials, financial resources, personnel, etc.);

2) Processes, implemented by a startup enterprise: organization of activities, supply of resources, creation of an innovative product, provision of services, sales;

3) Results and effectiveness (economic, social, environmental).

Fig. 1. The essence, components and objects of the strategic management accounting system at a startup enterprise

Source: it is formed by the authors.

Within the framework of the functioning of this system, accounting and analytical supports for strategic management decisions are ensured, the unified information subsystem of management is formed and the achievement of certain strategic goals of the company is controlled. Therefore, the strategic management accounting system should be formed as a multicomponent system and include not only the subsystem of accounting and information support, but also the subsystem of analysis, planning, monitoring, control, which will ensure its fulfillment of all management functions.

Management accounting, the use of its appropriate methods and tools at a startup venture should be adapted to the stages of the startup life cycle. We can generalize all phases and distinguish the following basic stages of the life cycle of a startup enterprise: 1) Starting a business and the initial stage; 2) Growth; 3) Extension. According to these stages of development the management accounting system is changing.

In the early stages of development, a startup is a micro or small enterprise, where it is advisable to appoint a person responsible for management accounting. At this stage, it is important to implement revenue and expenditure planning, draw up budgets, and analyze deviations from planned expenditures, which will help to control the use of own and borrowed funds. Therefore, at the stage of business creation and the beginning of the activity it is necessary to use such method of management accounting as budgeting.

Budgeting plays an important role in ensuring the rational use of resources and controlling the costs of running a startup. To achieve the goals of a company and to function effectively it is necessary to allocate and use resources rationally. In a resource shortage it is especially im- 
portant to minimize the costs of an enterprise. It causes the reasonability of planning. In the conditions of limited resources, it is necessary to choose among alternatives and consume resources on priority projects. Thus, managers should pay attention to budgeting, which is an essential component of the system of strategic management accounting [9].

Budgeting defers to the process of budget creation and is also one of the strategic management techniques. Budgeting is a managerial decision-making process regarding resource allocation, which results in budget formation. Budget is a financial plan, which reflects the amount of resources (cash and non-cash), required to implement strategic plans of a company over a certain period [9].

Budgeting has a range of advantages and brings benefits for a company (Figure 2). This instrument allows to plan and to forecast the expenses, to display a strategic plan in specific summarized costs in cash, to choose the most rational way of the of the resource consumption [9].

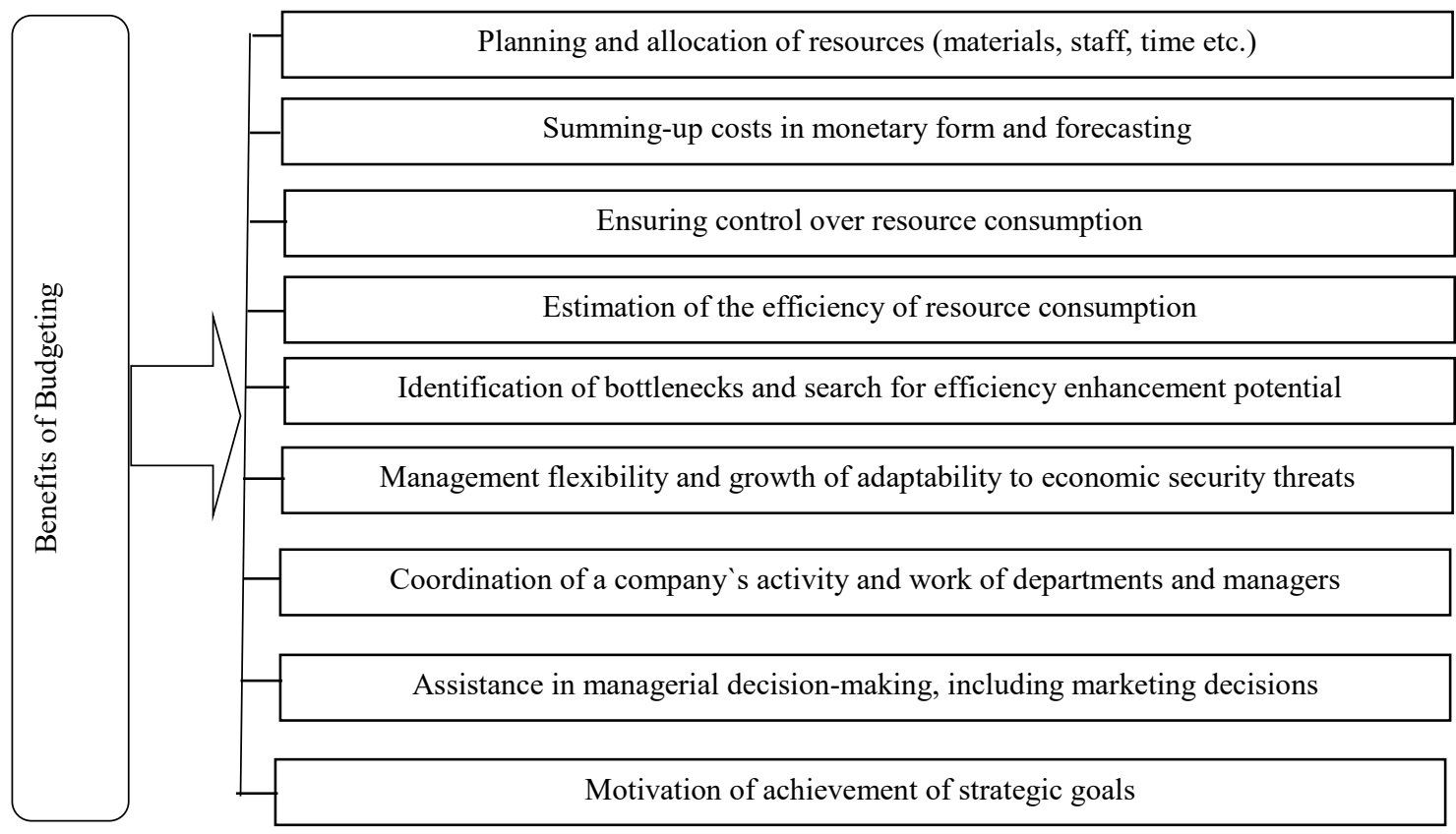

Fig. 2. The key benefits of budgeting for startup enterprise [9]

Budgeting plays an important role in achievement of the company's strategic goals. The company's budget should be formed in view of the priority directions of its functioning, defined in the strategy. At the same time, the implementation of strategic measures should be preceded by the preparation of a financial plan (budget). It is important to control the availability of the necessary resources at each stage of the strategy's implementation, to compare actual costs with planned and to analyze budget variance. Therefore, the process of budget generation should be integrated into the process of strategy formation [9].

With the increase in volume of orders, the expansion of markets, the increase in the number of employees, the startup company is entering a stage of growth. At this stage, it is reasonable to form a "Regulation on Strategic Management Accounting at a Startup Enterprise" and to expand the number of persons responsible for strategic management accounting. Accounting is becoming more strategic, as it is important to identify key performance indicators, to carry out the competitive analysis, and to determine the strategic directions for the future, taking into account the current position. For analytical cost and revenue accounting, it is advisable to elaborate and to implement internal reporting forms (for example, such as "Income statement by service type", "Cost report by economic elements"), as well as to form management reports for presentation to external users (in particular, "Startups' development funds report", Table 2). 
"Startups' development funds report" (Management report)

\begin{tabular}{|c|c|c|c|c|}
\hline Sources of funds & $\begin{array}{l}\text { Received for } \\
\text { development }\end{array}$ & $\begin{array}{c}\text { Consumed for } \\
\text { development }\end{array}$ & $\begin{array}{c}\text { Unused } \\
\text { funds }\end{array}$ & $\begin{array}{l}\text { Directions of } \\
\text { consumption }\end{array}$ \\
\hline \multicolumn{5}{|c|}{ Received funds } \\
\hline \multicolumn{5}{|l|}{ State institutions funds } \\
\hline \multicolumn{5}{|l|}{ Grant funds } \\
\hline \multicolumn{5}{|l|}{ Business angels' funds } \\
\hline \multicolumn{5}{|l|}{ Venture funds } \\
\hline \multicolumn{5}{|l|}{ Crowdfunding } \\
\hline \multicolumn{5}{|l|}{ Charity assistance } \\
\hline \multicolumn{5}{|l|}{ Other funds } \\
\hline$\ldots$ & & & & \\
\hline \multicolumn{5}{|c|}{ Own funds } \\
\hline \multicolumn{5}{|l|}{ Ownership capital } \\
\hline$\ldots$ & & & & \\
\hline Total funds & & & & $\mathrm{x}$ \\
\hline
\end{tabular}

Source: it is formed by the authors.

Considering that innovation is the base of the startups activity, it is recommended to form an internal report "Costs and results of innovative activity of a startup enterprise". This report allows to control the costs for innovative products, created by the enterprise. The elaborated report form is presented in Table 3.

Table 3

"Costs and results of innovative activity of a startup enterprise" (Internal report)

\begin{tabular}{|l|l|l|l|}
\hline \multicolumn{1}{|c|}{ Indexes Costs for innovation creation } & \multicolumn{1}{|c|}{ Pact } & Deviation from the plan \\
\hline \multicolumn{3}{|c|}{ Revenues from the sale of innovative products } & \\
\hline Costs for innovative production & & & \\
\hline Costs for innovative design & & & \\
\hline Other costs for innovation creation & & \\
\hline \multicolumn{3}{|c|}{ Innovative activity of a startup enterprise } & \\
\hline $\begin{array}{l}\text { Volume of innovative products sold: } \\
\text { - by types: }\end{array}$ & & \\
\hline Total revenue from innovative products & & \\
\hline \multicolumn{2}{|c|}{} \\
\hline $\begin{array}{l}\text { Quantity of developed innovative technologies/ } \\
\text { equipment }\end{array}$ & & \\
\hline $\begin{array}{l}\text { Quantity of purchased innovative technolo- } \\
\text { gies/equipment }\end{array}$ & & & \\
\hline Number of implemented innovative technologies & & & \\
\hline$\ldots$ & & & \\
\hline
\end{tabular}

Source: it is formed by the authors

In the case of effective management of the startup and its successful operation, the startup enterprise expands its activities and scales its business. At the stage of expansion, it is possible to create a department of strategic management accounting at the enterprise. There is a reorientation of the management accounting system to solve strategic development problems (making strategic management decisions, evaluating development alternatives, choosing an alternative and developing the strategy).

At this stage, it is advisable to use a strategic management accounting tool, such as the Balance Scorecard, which will allow to evaluate the performance of a startup business based on financial and non-financial indicators. In addition, it is recommended to prepare the management reports, in particular - "Management Commentary", which will provide a wide range of users with transparent and complete information on the results, prospects of the startup enterprise and risk management system. In order to eliminate the complexity of management 
ФІНАНСОВІ РЕСУРСИ: ПРОБЛЕМИ ФОРМУВАННЯ ТА ВИКОРИСТАННЯ

accounting, it is possible to ensure the automation of management accounting at this stage. Directions of the formation of a strategic management accounting system for a startup enterprise at various stages of its development are summarized in Table 4.

Table 4

Directions of the formation of a strategic management accounting system for a startup enterprise at various stages of its development

\begin{tabular}{|c|c|}
\hline $\begin{array}{l}\text { Core stages of } \\
\text { startups`life cycle }\end{array}$ & The complex of measures \\
\hline Start of a business & $\begin{array}{l}\text { - Determination of the person responsible for management accounting at the enterprise } \\
\text { and entering these responsibilities in the job description (usually chief accountant, ac- } \\
\text { countant or economist); } \\
\text { - Planning of income and expenses at a startup enterprise, introduction of cost standards, } \\
\text { budget formation, carrying out the variance analysis; } \\
\text { - Identification of the responsibility centers on the basis of organizational and manage- } \\
\text { ment structure, responsibility accounting; } \\
\text { - Definition of the algorithm of decision-making. }\end{array}$ \\
\hline Growth & $\begin{array}{l}\text { - Formation of "Regulations on Strategic Management Accounting at a Startup Enter- } \\
\text { prise"; } \\
\text { - Expanding the number of persons responsible for management accounting; } \\
\text { - Defining the criteria for evaluating the effectiveness of management decisions; } \\
\text { - Formation of a system of key performance indicators (KPI) and analysis of factors that } \\
\text { affect performance; } \\
\text { - Carrying out competitive analysis and identifying prospects for expanding startup activities; } \\
\text { - Formation of internal reports such as "Income statement by service type", "Cost report } \\
\text { by economic elements", "Costs and results of innovative activity of a startup enterprise" } \\
\text { for the purpose of accounting and control of income and expenses by their types; } \\
\text { - Formation of reports for external and internal users, in particular - the "Startups' devel- } \\
\text { opment funds report" in order to provide the information concerning the directions of con- } \\
\text { sumption of the received funds to all stakeholders. }\end{array}$ \\
\hline Expansion & $\begin{array}{l}\text { - Formation of the department of management accounting at the enterprise; } \\
\text { - Reorientation of the management accounting system to solve strategic development } \\
\text { problems (making strategic management decisions, evaluating development alternatives, } \\
\text { selecting alternatives and developing strategies); } \\
\text { - Applying of Balance Scorecard method to evaluate the performance of a startup busi- } \\
\text { ness (the system will include financial and non-financial indicators to evaluate the per- } \\
\text { formance of a startup); } \\
\text { - Automation of management accounting (for example, the application of the manage- } \\
\text { ment accounting and reporting module ERP SAP R/3); } \\
\text { - Formation of "Management Commentary" with the purpose to ensure a wide range of } \\
\text { users with transparent and complete information on the results and prospects of a startup. }\end{array}$ \\
\hline
\end{tabular}

Source: it is formed by the authors.

For today enterprises are operating under conditions of global digitization. In practice, it appears through automation of accounting, control and management in general. At the stage of expansion of a startup, an increasing amount of information is a subject to systematization, processing, analysis, and storage. Therefore, it may be decided to automate the strategic management accounting at a startup enterprise at this stage.

Among software products, which are more available for small business entities are: Project Management Systems/Software; Customer Relations Management; systems of collective work on information (wiki projects, discussion platforms, forums); Enterprise Resource Planning System, Enterprise Content Management, Business Processes Management; special ordering systems [10].

One of the possible solutions for automating the accounting is to implement ERP SAP R/3 (Enterprise Resource Planning System). ERP integrates these processes into the unified system: finance, HR, manufacturing, supply chain, services, procurement, and others. New ERP systems use the latest technologies - such as machine learning and AI - to provide intelligence, visibility, and efficiency across every aspect of a business [11]. 
ФІНАНСОВІ РЕСУРСИ: ПРОБЛЕМИ ФОРМУВАННЯ ТА ВИКОРИСТАННЯ

This system allows to automate financial and management accounting, control processes, management of information flows and projects. Implementation of the ERP will create the unified informational system, that takes into account all aspects of the startup's activities and includes information on the planning, supply, production (service), sales, customer interaction and decisions at all levels of management.

Accounting automation has a range of advantages for a startup:

- reducing the complexity of accounting work;

- providing complete and reliable information about the financial status and performance of a startup enterprise;

- carrying out comprehensive analysis and identifying factors of detrimental effect;

- planning and forecasting, operational and strategic management based on an unified information base, etc.

In addition, accounting automation will reduce the risk of error by accounting staff and management accounting professionals, as well as will improve the control over the correctness of reporting information (Figure 3).

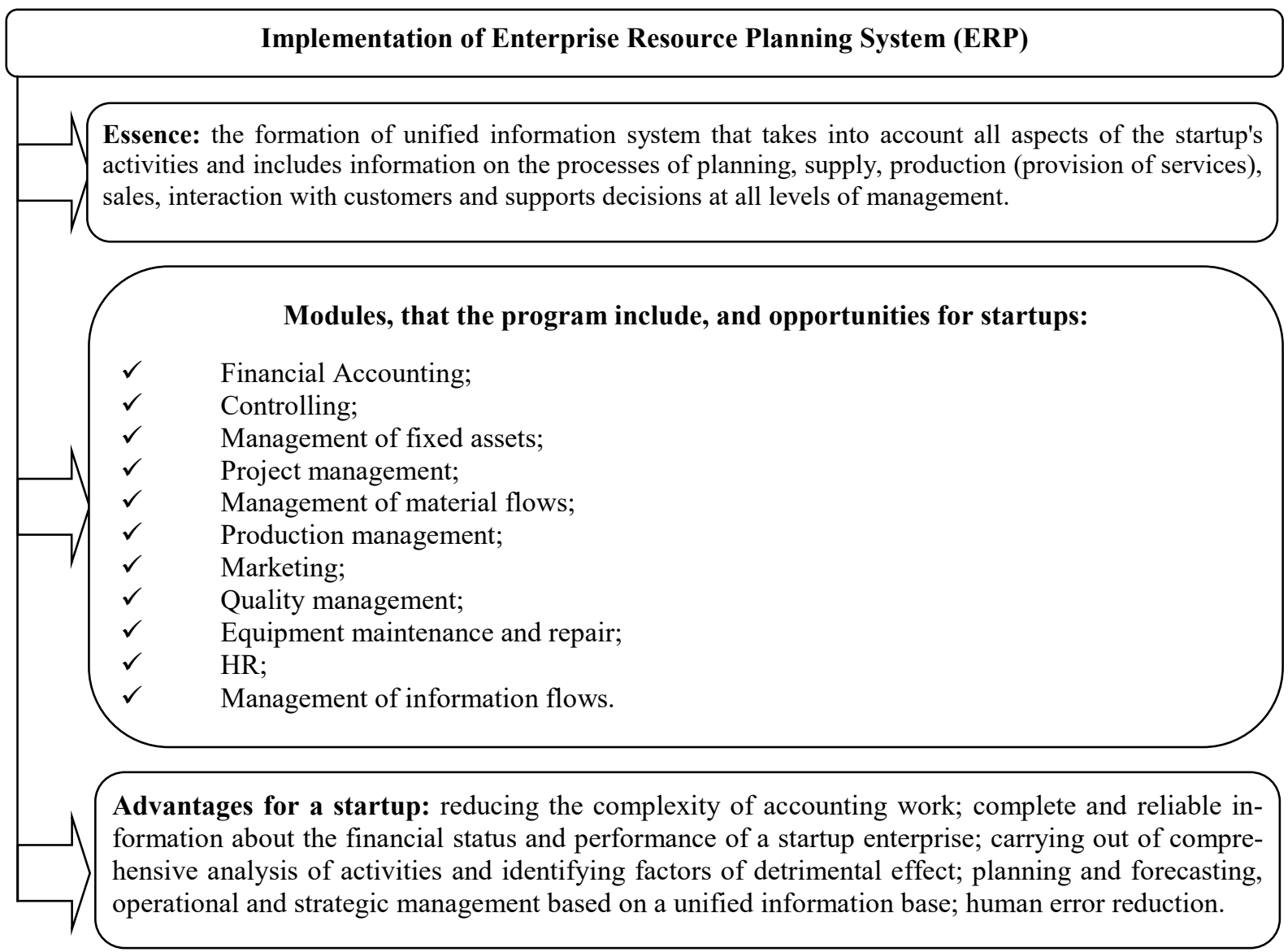

Fig. 3. Directions for accounting and control automation at a startup enterprise

Source: it is formed by the authors.

It is to be noted, that during the implementation of information and computer technologies into the management system, it is necessary to take into account the potentialities of an entity, its specific and particular features (amount of business, financial resources, personnel, current state, prospects, risks etc.). Definitely, "the digitalization path of each enterprise will be individual in both approach and time" [12, p. 2294], but managers should be ready for changes and be conscious of "the feasibility and relevance of active measures introduction of new technologies" [12, p. 2294]. 
ФІНАНСОВІ РЕСУРСИ: ПРОБЛЕМИ ФОРМУВАННЯ ТА ВИКОРИСТАННЯ

It is important to provide the monitoring in order to evaluate the current state of the strategic management accounting system at a startup enterprise and to determine the directions of its improvement. For this purpose, it is advisable to use methods of observation, documentary verification, interviewing of specialists in management accounting, data analysis. Key questions about management accounting at an enterprise, including strategic ones, are presented in the elaborated questionnaire, which can be used to monitor the strategic management accounting system at a startup enterprise (Table 5).

Table 5

\section{Questionnaire for monitoring the strategic management accounting system} at a startup enterprise

\begin{tabular}{|c|c|c|c|}
\hline $\begin{array}{c}\text { Key questions (the list of key questions can be refined depending on the stage of } \\
\text { startups 'life cycle and management needs) }\end{array}$ & Yes & No & Notes \\
\hline $\begin{array}{l}\text { Has the company established a management accounting department or other structural } \\
\text { unit that is responsible for managing accounting? }\end{array}$ & & & \\
\hline Are management accounting responsibilities for specific professionals defined? & & & \\
\hline Is the "Regulation on management accounting" approved at the enterprise? & & & \\
\hline Does the accounting policy include a chapter dedicated to management accounting? & & & \\
\hline Have all job descriptions for management professionals been developed and approved? & & & \\
\hline Does the company use any special software for accounting automation? & & & \\
\hline Has the company developed internal reporting forms? & & & \\
\hline What management reports does the company prepare? & & & \\
\hline Are the responsibility centers defined at the enterprise? & & & \\
\hline Does the company have internal control procedures? & & & \\
\hline Is the cost planning carried out? Are the costing standards applied in planning? & & & \\
\hline Is the break-even analysis carried out? & & & \\
\hline Is non-financial reporting being prepared at the enterprise? & & & \\
\hline $\begin{array}{l}\text { Has the enterprise established a system of accounting and analytical support for risk } \\
\text { management? }\end{array}$ & & & \\
\hline Are Key Performance Indicators monitored? & & & \\
\hline Are Key Success Factors monitored for the achievement of the goal of a startup business? & & & \\
\hline Are the results of activities in the context of responsibility centers monitored? & & & \\
\hline Are strategic management decisions made at the enterprise? & & & \\
\hline Is an enterprise strategy developed? & & & \\
\hline
\end{tabular}

Source: it is formed by the authors.

The questionnaire includes a list of key questions concerning strategic management accounting, that help startups ' representatives to evaluate the state of this system. This, in turn, reveals the shortcomings and gaps in the organization of management accounting system as a whole and allows to determine the directions of its improvement.

Conclusions and recommendations. The conducted research of peculiarities of formation of strategic management accounting system for startups allows to form the following conclusions:

1. Strategic management accounting is a system, in which the information on the internal and external environments of the enterprise is accumulated, analyzed, and stored in order to support management decisions and business strategy formation. It provides accounting and analytical support for strategic management of the enterprise. The main advantage of the strategic management accounting is the formation of a unified information base for strategic management decisions, which includes data about not only the internal, but also the external environment of the enterprise (market development trends, the state of competitors, needs and interests of consumers, etc.). It allows to manage the results comprehensively, to formulate a business strategy based on this information, to monitor and evaluate the level of achievement of strategic goals, to adjust the strategy and to develop strategic plans for departments of the organization. Implementation of a strategic accounting system at an enterprise helps to ensure its resilience to external threats, flexibility, and adaptability to new challenges. 
ФІНАНСОВІ РЕСУРСИ: ПРОБЛЕМИ ФОРМУВАННЯ ТА ВИКОРИСТАННЯ

2. The formation of a strategic accounting system will contribute to the implementation of timely and rational management decisions regarding the current and strategic directions of the startup enterprise in order to achieve the goals of the startup. This process should be interrelated with the startups' life cycle and managers should take into account the stage of startups development during system formation. The strategic management accounting system will be constantly improved from the stage of creation of the startup to its growth. The integrated approach to the formation of the strategic management accounting system, proposed in the paper, ensure its creation as a multicomponent system, which includes the subsystem of accounting, information support, analysis, planning, monitoring, control in order to ensure the achievement of the strategic goals of the startup enterprise.

3. Management accounting automation is appropriate at the startups' expansion stage and can be realized by implementing such system, as ERP SAP R/3, the benefits of which are to reduce the complexity of accounting procedures and the risk of accounting errors, to create a unified information base for decision-making, to provide timely and accurate information about the startups` results.

4. Budgeting, cost control, formation of an internal reporting system for cost management play an important role in ensuring the resource management of startups. Since innovation is at the heart of startups and a large proportion of costs are the costs for creating innovative products, it is necessary to control costs for innovations. For the analytical accounting of such costs, it is recommended to prepare an internal report "Costs and results of innovative activity of a startup enterprise", the form of which is prepared. In addition, in order to cover information about the amount and direction of funds used by the startup (business angel funds, venture funds, grant funds, etc.), it is reasonable to form a "Startups' development funds report", which will ensure stakeholders with transparent information concerning startups` activity and resource consumption.

5. In order to estimate the current state of the strategic management accounting system and to identify its strengths and weaknesses, it is advisable to monitor this system, using a developed questionnaire, that will help to define opportunities for continuous improvement of the strategic management accounting system at a startup enterprise. The strategic management accounting system is a dynamic system, that are to be improved according to the new stages of the startups` life cycle and the level of automation of the accounting and internal control system.

\section{References}

1. Simmonds, K. (1981). Strategic management accounting. Management Accounting (UK), 59 (4), 26-29 [in English].

2. Bromwich, M. (1990). The case for strategic management accounting: the role of accounting information for strategy in competitive markets. Accounting, Organizations and Society, 15, 27-46 [in English].

3. Innes, J. (1998). Strategic management accounting. Handbook of Management Accounting, 2 [in English].

4. Ma, Y.\& Tayles, M. (2009). On the emergence of strategic management accounting: an institutional perspective. Accounting and Business Research, 39 (5), 473-495 [in English].

5. Pushkar, M.S. (1999). Tendentsii ta zakonomirnosti rozvytku bukhhalterskoho obliku v Ukraini (teoretyko-metodolohichni aspekty) [Trends and patterns of accounting development in Ukraine (theoretical and methodological aspects)]. Ternopil [in Ukrainian].

6. Atamas, P.Y. (2006). Upravlinskyi oblik [Management accounting]. K.: Center for Educational Literature [in Ukrainian].

7. Shevchuk, V.R. (2014). Stratehichnyi upravlinskyi oblik yak informatsiine pidgruntia stratehichnoho menedzhmentu pidpryiemstva [Strategic management accounting information as a basis of strategic management enterprise]. Visnyk Natsionalnoho universytetu "Lvivska politekhnika”. Menedzhment ta pidpryiemnytstvo $v$ Ukraini: etapy stanovlennia i problemy rozvytku - Bulletin 
ФІНАНСОВІ РЕСУРСИ: ПРОБЛЕМИ ФОРМУВАННЯ ТА ВИКОРИСТАННЯ

of the National University "Lviv Polytechnic». Management and entrepreneurship in Ukraine: stages of development and development problems, 797, 417-422. Retrieved from http://nbuv.gov.ua/ UJRN/ VNULPM_2014_797_58.

8. Tomilets, K.I. (2017) Stratehichnyi upravlinskyi oblik yak skladova systemy oblikovoanalitychnoho zabezpechennia staloho rozvytku pidpryiemstva [Strategic management accounting as part of the system of accounting and analytical support for sustainable development of the enterprise]. Yunist nauky - 2017: sotsialno-ekonomichni ta humanitarni aspekty rozvytku suspilstva: zbirnyk tez Mizhnarodnoi naukovo-praktychnoi konferentsii studentiv, aspirantiv i molodykh vchenykh - Youth Science - 2017: Socio-Economic and Humanitarian Aspects of Society Development: Proceedings of the International Scientific and Practical Conference of Students, Graduate Students and Young Scientists (Chernihiv, April 26-27, 2017). Chernihiv: CNTU, 195-196 [in Ukrainian].

9. Hnedina, K.V. \& Vertiiko, A.A. (2018). Budgeting in strategic management accounting: essence and benefits. Bukhhalterskyi oblik, opodatkuvannia, analiz i audyt: suchasnyi stan, problemy ta perspektyvy rozvytku : tezy dopovidei IV Mizhnarodnoi naukovo-praktychnoi konferentsii [Accounting, taxation, analysis and audit: current state, problems and prospects of development: abstracts of the IV International scientific-practical conference] (Chernihiv, November 27, 2018). Chernihiv: CNTU, 60-61 [in English].

10. Volot, O. \& Kolotok, V. (2019). Analysis of international practices of using information and communication technology in small business on the case of Israel. Problems and Prospects of Economy and Management, 3 (19), 220-229 [in English].

11. What is ERP? Retrieved from https://www.sap.com/products/what-is-erp.html.

12. Akymenko O., Petrovska A., Zholobetska M. \& Skrytskyi D. (2020). Digital development of the economy and its role in improving the international competitiveness of Ukraine. International Journal of Advanced Science and Technology, 29 (8s), 2290-2296. Retrieved from http://sersc.org/journals/index.php/IJAST/article/view/14668.

\section{References (in language original)}

1. Simmonds K. Strategic management accounting. Management Accounting (UK). 1981. № 59 (4). P. 26-29.

2. Bromwich M. The case for strategic management accounting: The role of accounting information for strategy in competitive markets. Accounting, Organisations and Society. 1990. № 15. P. 27-46.

3. Innes J. Strategic management accounting. Handbook of management accounting. London: Gee, 1998.

4. Ma Y., Tayles M. On the emergence of strategic management accounting: an institutional perspective. Accounting and Business Research. 2009. № 39 (5). P. 473-495.

5. Пушкар М.С. Тенденції та закономірності розвитку бухгалтерського обліку в Україні (теоретико-методологічні аспекти) : монографія. Тернопіль, 1999. 424 с.

6. Атамас П. Й. Управлінський облік. Київ : Центр навчальної літератури, 2006. 440 с.

7. Шевчук В. Р. Стратегічний управлінський облік як інформаційне підгрунтя стратегічного менеджменту підприємства. Вісник Національного університету «Львівська політехніка». Менеджмент та підприємництво в Україні: етапи становлення $і$ проблеми розвитку. 2014. № 797. C. 417-422. URL: http://nbuv.gov.ua/UJRN/VNULPM_2014_797_58.

8. Томилець К. І. Стратегічний управлінський облік як складова системи обліковоаналітичного забезпечення сталого розвитку підприємства. Юність науки - 2017: соціальноекономічні та гуманітарні аспекти розвитку суспільства : збірник тез Міжнародної науковопрактичної конференції студентів, аспірантів і молодих вчених (м. Чернігів, 26-27 квітня 2017 р.). Чернігів : ЧНТУ, 2017. С. 195-196.

9. Hnedina K. V., Vertiiko A. A. Budgeting in strategic management accounting: essence and benefits. Бухгалтерський облік, оподаткування, аналіз і аудит: сучасний стан, проблеми та перспективи розвитку : тези доповідей IV Міжнародної науково-практичної конференції (м. Чернігів, 27 листопада 2018 р.). Чернігів: ЧНТУ, 2018. С. 60-61. 
ФІНАНСОВІ РЕСУРСИ: ПРОБЛЕМИ ФОРМУВАННЯ ТА ВИКОРИСТАННЯ

10. Volot O., Kolotok V. Analysis of international practices of using information and communication technology in small business on the case of Israel. Problems and prospects of economics and management. 2019. № 3 (19). C. 220-229.

11. What is ERP? URL: https:/www.sap.com/products/what-is-erp.html

12. Akymenko O., Petrovska A., Zholobetska M., Skrytskyi D. Digital development of the economy and its role in improving the international competitiveness of Ukraine. International Journal of Advanced Science and Technology. 2020. № 29 (8s). P. 2290-2296. URL: http://sersc.org/journals/index.php/IJAST/article/view/14668.

Hnedina Kateryna - PhD in Economics, Assistant Professor, Assistant Professor of the Department of Accounting, Taxation and Audit, Chernihiv National University of Technology (95 Shevchenka Str., 14035 Chernihiv, Ukraine).

Гнедіна Катерина Володимирівна - кандидат економічних наук, доцент, доцент кафедри бухгалтерського

обліку, оподаткування та аудиту, Чернігівський національний технологічний університет (вул. Шевченка, 95,

м. Чернігів, 14035, Україна).

Гнедина Екатерина Владимировна - кандидат экономических наук, доцент, доцент кафедры бухгалтерского учета, налогообложения и аудита, Черниговский национальный технологический университет (ул. Шевченко, 95, г. Чернигов, 14035, Украина).

E-mail: gkv2015oa@gmail.com

ORCID: https://orcid.org/0000-0001-9471-0932

ResearcherID: F-1707-2014

Vertiiko Artem - Master's Degree Student, Chernihiv National University of Technology (95 Shevchenka Str., 14035 Chernihiv, Ukraine).

Вертійко Артем Андрійович - магістрант, Чернігівський національний технологічний університет (вул. Шевченка, 95, м. Чернігів, 14035, Україна).

Вертейко Артём Андреевич - магистрант, Черниговский национальный технологический университет (ул. Шевченко, 95, г. Чернигов, 14035, Украина).

E-mail: vertiykoartem1998@gmail.com 